www.jmscr.igmpublication.org Impact Factor 5.244

Index Copernicus Value: 5.88 ISSN (e)-2347-176x ISSN (p) 2455-0450 crossref DOI:_http://dx.doi.org/10.18535/jmscr/v4i6.77

Journal Of Medical Science And Clinical Research

\title{
Echocardiographical Evaluation And Cardiovascular Changes In Chronic Obstructive Pulmonary Disease Patients In Tertiary Care Hospital
}

\author{
Authors \\ Saurabh ${ }^{1}$, Lalit Singh ${ }^{2}$, Anurag Agarwal ${ }^{2}$, Rajeev Tandon ${ }^{3}$, Hemant kumar \\ ${ }^{1}$ JR-3 Pulmonary Medicine \\ ${ }^{2}$ Professor of Pulmonary Medicine \\ ${ }^{3}$ Assistant professor of Pulmonary Medicine \\ Dept of Pulmonary Medicine, Shri Ram Murti Smarak Institute of Medical Sciences, Bareilly \\ Corresponding Author \\ Dr Saurabh Yadav
}

JR-3 Department of Pulmonary Medicine

SRMS IMS Bareilly, Pin-243001

Email:dr.saurabhyadav76@gmail.com

\begin{abstract}
INTRODUCTION: Chronic obstructive pulmonary disease (COPD) is a disease characterized by progressive poorly reversible airway destruction. Cardiovascular disease accounts for significant morbidity and mortality in chronic obstructive pulmonary disease (COPD). Its prevalence and mechanisms of association have not been elucidated. The study aimed to assess the prevalence of echocardiographic abnormalities and potential risk factors in patients with COPD.
\end{abstract}

MATERIALS AND METHODS: A total of 86 COPD patients were enrolled in the present study. All patients were subjected to full medical history and clinical examination, chest radiography, complete blood count, lipid profile, spirometry, 2D-echocardiography.

RESULTS: 86 patients included in our study. Out of 86 patients, 74( 86\%) were male and 12 ( $14 \%$ ) were females. Male to female ratio was 6.1:1. Mean age was $58.2 \pm 12.7$ years. Severity of COPD patients classify according to GOLD criteria. Out of 86 patients, 15 patients had FEVI< $80 \%$ of predicted, $10 \%$ patients had mod.(FEVI 50-80\%), 24 had severe and 37 had very severe disease. Pulmonary artery hypertension was defined as SPAP> $30 \mathrm{mmHg}$ which was seen in 40 cases (46.5\%). Out of 50 patients, 15 (17.4\%) patients had mild, 5 (10.5\%) had moderate and 18 (18.6\%) had severe pulmonary hypertension, 12 (13.6\%) patients had right ventricular systolic dysfunction, 11 (12.8\%) had left ventricular systolic dysfunction and left ventricular hypertrophy. 16 (18.6\%) had cor pulmonale.

CONCLUSION: Echocardiography is helpful in early detection of cardiac complication in COPD patients.

KEY WORDS: Chronic obstructive pulmonary disease, pulmonary hypertension, cor pulmonale, left ventricular hyperterophy. 


\section{INTRODUCTION}

Chronic obstructive pulmonary disease (COPD) is a complex and heterogeneous clinical syndrome found in $6-8 \%$ of entire population ${ }^{1}$. It is a major cause of morbidity and $4^{\text {th }}$ leading cause of death in the world ${ }^{2}$ and further increases in prevalence and mortality can be predicted in the coming decades.

COPD is associated with significant extra pulmonary (systemic effects) among which cardiac manifestations are most common. Cardiovascular diseases account for approximately $50 \%$ of all hospitalizations and nearly onethird of all deaths, if forced expiratory volume in one second $\left(\mathrm{PEF}_{1}\right)>50 \%$ of predicted ${ }^{3}$.

COPD affects pulmonary blood vessels, right ventricle as well as left ventricle leading to development of PHT, cor pulmonale, right ventricular dysfunction and left ventricular dysfunction.

There was less data in this segment of correlation of cardiopulmonary diseases, so this study was planned to confirm various cardiovascular manifestations in COPD patients and to find out correlation of cardiovascular complications with its severity.

\section{Material And Methods}

86 COPD patients were included in this study who were confirmed by clinical history, radiology of chest and pulmonary function test selected from Pulmonary Medicine Department SRMS-IMS, Bareilly from Jan- 2014 to Jan- 2016

ECG and Echocardiography was also done

All the patients were investigated by spirometry and diagnosed and classified according to GOLD guidelines $2010^{4}$.

All patients having known respiratory diseases like old treated Pulmonary Tuberculosis, Bronchial Asthma; as well as diabetes, Systemic Hypertension, Rheumatic fever, Congenital Ischemic Heart diseases were excluded.

All patients were undertaken for 2D echocardiography as per recommendation of American Society of Echocardiography ${ }^{5,6}$.

\section{RESULT}

86 patients included in our study. Out of 86 patients, 74( $86 \%$ ) were male and 12( $14 \%$ ) were females. Male to female ratio was 6.1:1. Mean age was $58.2 \pm 12.7$ years.

Table-1: Sex Distribution Of COPD Patients

\begin{tabular}{|l|l|l|}
\hline SEX & N & $\%$ \\
\hline Male & 74 & $86 \%$ \\
\hline Female & 12 & $14 \%$ \\
\hline
\end{tabular}

Severity of COPD patients classify according to GOLD criteria. Out of 86 patients, 15 patients had $\mathrm{FEV}_{1}<80 \%$ of predicted, $10 \%$ patients had mod.(FEV $150-80 \%), 24$ had severe and 37 had very severe disease.

Table-2: Patients classification according to severity of COPD

\begin{tabular}{|l|l|l|}
\hline Severity of COPD & $\mathrm{N}$ & $\%$ \\
\hline Mild- $\mathrm{FEV}_{1}<80 \%$ predicted & 15 & $17.4 \%$ \\
\hline Moderate $50-80 \%$ predicted & 10 & $11.5 \%$ \\
\hline Severe $30-50 \%$ predicted & 24 & $27.9 \%$ \\
\hline Very severe $<30 \%$ predicted & 37 & $43.2 \%$ \\
\hline
\end{tabular}

$\mathrm{FEV}_{1}$ : Forced expiratory volume in one second On echocardiography, 10 patients had normal study. Measurable tricuspid regurgitation was observed in 42 patients,.

Pulmonary artery hypertension was defined as SPAP> $30 \mathrm{mmHg}$ which was seen in 40 cases ( $46.5 \%)$. Out of 50 patients, $15(17.4 \%)$ patients had mild, 5 (10.5\%) had moderate and 18 (18.6\%) had severe pulmonary hypertension.

In our study, 12 ( $13.6 \%)$ patients had right ventricular systolic dysfunction, 11 (12.8\%) had left ventricular systolic dysfunction and left ventricular hypertrophy. 16 ( $18.6 \%)$ had cor pulmonale.

It has been seen that the severity of cardiac manifestations increases as the severity of COPD increases. 
Table-3: Echocardiography finding in COPD patients.

\begin{tabular}{|l|l|l|}
\hline & $\mathrm{N}$ & $\%$ \\
\hline Normal & 10 & 11.6 \\
\hline Pulmonary hypertension & & \\
(SPAP>30mmHg) & & \\
Mild 30-50 & 13 & 17.4 \\
Moderate 50-70 & 09 & 10.5 \\
Severe >70 & 16 & 18.6 \\
\hline RVSD & 12 & 13.6 \\
LVH & 11 & 12.8 \\
LVDD & 30 & 34.9 \\
LVSD & 11 & 12.8 \\
Cor pulmonale & 10 & 11.6 \\
\hline
\end{tabular}

RVSD: Right ventricular systolic diameter

LVH: Left ventricular hypertrophy

LVDD: Left ventricular diastolic dysfunction

LVSD: Left ventricular systolic diameter

\section{DISCUSSION}

COPD is the most common medical problem in rural population, according to a hospital based evaluation and has significant mortality and morbidity. The cardiac complications are numerous. Significant structural changes occur in the pulmonary circulation in patients with COPD. The present study included 86 patients; out of this, 74 patients were male and 12 were females. The male to female ratio was $6.1: 1$. The incidence of smoking was more in males as compared to females. In the present study,40 (46.5\%) had pulmonary hypertension. Pulmonary hypertension is a common complication seen in patients with advanced chronic obstructive pulmonary disease (COPD). It has clear effects on both morbidity and mortality ${ }^{7}$. Although the true prevalence of $\mathrm{PH}$ in COPD is unknown, an elevation of pulmonary arterial pressure is reported to occur in $20-90 \%$ of patients when measured by right heart catheterization with some evidence that pulmonary hemodynamics worsen with worsening airflow obstruction $8,9,10,11,12,13$.

Cor pulmonale is present in $11.6 \%$ of patients in our study. Approximately $25 \%$ patients with COPD eventually develop cor pulmonale. Cor pulmonale was found in $40 \%$ patients with COPD in one autopsy study ${ }^{14,15}$.
Some study indicate that LV function remains normal in persions with COPD, whereas others suggest that LV dysfunction may be present ${ }^{16,17}$. In our study, left ventricular dysfunction (LVSD) is present in $12.8 \%$ patients, in previous studies it was present in $4 \%-32 \%$ patients of COPD ${ }^{18-21}$. In our study LVDD was present in $34.9 \%$ of patients, left ventricular hypertrophy $(\mathrm{LVH})$ was present in $12.8 \%$ patients in our study, in previous study $\mathrm{LVH}$ was found in $25 \%-60 \%$ patients $^{22}$.

\section{CONCLUSION}

To conclude, high prevalence of pulmonary hypertension, cor pulmonale, left ventricular dysfunction complicating COPD, more so with more severe COPD. The screening must to be done in all COPD patients to rule out cardiac complications. This would contribute to the assessment of prognosis in these patients and assist in identifying individuals likely to suffer increased mortality and morbidity warranting close monitoring and intense treatment.

\section{REFERENCES}

1. Murray CJ, Lopez AD: Alternative projections of mortality and disability by cause 1990- 2020: Global Burden Disease Study. Lancet, 1997; 349: 1498-1504.

2. World Health Report, World Health Organization, Geneva. 2000.

3. Anthonisen N, Connett JE, Kiley JP, Altose MD, Bailey WC, et al. Effects of Smoking Intervention and the Use of an Inhaled Anticholinergic Bronchodilator on the Rate of Decline of FEV1. JAMA.1994;272:1497-1505

4. Global strategy for the diagnosis, management, and prevention of chronic obstructive pulmonary disease, Global initiative for chronic obstructive pulmonary disease (GOLD), 2010.

5. Schmailzl KJG. Conventional Echocardiography: Examination Procedure, Fundamental measurement and 
Assessment Tasks. In Schmailzl JG, Ormerod O, Editors. Ultrasound in Cardiology (1st ed.). Berlin: Blackwell Science 1994; 49-8.

6. Oh JK, Seward JB, Tajik AJ. The Echo Manual: the Mayo Clinic (13rd ed.). New Delhi: Lippincott Williams 2006; 7-28.

7. Chemla D, Castelain V, Humbert $M$, Simonneau JLHG, Lecarpentier Y, Hervé P. New Formula for Predicting Mean Pulmonary Artery Pressure Using Systolic Pulmonary Artery Pressure. Chest. 2004;126:1313-17.

8. Libby P, Bonow RO, Zipes DP, Mann DL, editors. 8 th. Philadelphia: Saunders; 2008. Braunwald's Heart Disease; p. 251.

9. Weitzenblum E, Hirth C, Ducolone A, Mirhom R, Rasaholinjanahary J, Ehrhart M. Prognostic value of pulmonary artery pressure In chronic COPD. Thorax. 1981;36:752-8.

10. Weitzenblum E, Sautegeau A, Ehrhart M, Mammosser M, Hirth C, Roegel E. long term course of pulmonary artery pressure In chronic COPD. Am Rev Respir Dis. 1984;130:993-8.

11. Burrows B, Kettel LJ, Niden AH, Rabinowitz M, Diener CF. Patterns of cardiovascular dysfunction in COPD. $\mathrm{N}$ Engl J Med. 1972;286:912-8.

12. Fishman AP. State of the art: Chronic cor pulmonale. Am Rev Respir Dis. 1976;114:775-94.

13. Pietra G. Pathology of the pulmonary vasculature and heart. In: Cherniack $\mathrm{N}$, editor. COPD. 1996. pp. 21-6.

14. Rigolin VH, Robiolio PA, Wilson JS, Harrison JK, Bashore TM. The forgotten chamber: The importance of the right ventricle. Cathet Cardiovasc Diagn. 1995;35:18-28.

15. Fishman AP. State of the art: Chronic Cor Pulmonale. Am Rev Respire Dis. 1976;114:775-94.
16. Murphy ML, Adamson J, Hutcheson F. Left ventricular hypertrophy in patients with chronic bronchitis and emphysema. Ann Intern Med. 1974;81:307-13.

17. Fluck DC, Chandrasekar RG, Gardner FV. Left ventricular hypertrophy in chronic bronchitis. Br Heart J.1966;28:92-7.

18. Render ML, Weinstein AS, Blaustein AS. Left ventricular dysfunction in deteriorating patients with chronic obstructive pulmonary disease. Chest. 1995;107:162-8.

19. Vizza CD, Lynch JP, Ochoa LL, Richardson G, Trulock EP. Right and left ventricular dysfunction in patients with severe pulmonary disease. Chest. 1998;113:576-83.

20. Jardin F, Gueret P, Prost JF, Farcot JC, Ozier Y, Bourdarias JP. Two-dimensional echocardiographic assessment of left ventricular function in chronic obstructive pulmonary disease. Am Rev Respir Dis.1984;129:135-42.

21. Louridas G, Patakas D, Stavropoulos C. Left ventricular function in patients with chronic obstructive pulmonary disease. Cardiology. 1981;67:73-80.

22. Poddar AK, Chakraborti BN, Ghosh JL, Nandy S, Hazra S. Assessment of left ventricular function in patients of COPD :Ind J Tub. 1997;44:181. 